\title{
Mapping of Soil Fertility Using Landsat Data in Lautém District, Timor-Leste
}

\author{
Romaldo Da Costa Ximenes ${ }^{\mathrm{a}, \mathrm{b} *}$, Takahiro Osawa ${ }^{\mathrm{c}, \mathrm{d}}$, I Wayan Nuarsa ${ }^{\mathrm{b}}$ \\ a Universidade Oriental De Timor Lorosa'e, Avenida Becora, Cristo Rei, Dili, Timor-Leste \\ ${ }^{b}$ Graduate Study of Environmental Sciences, Udayana University, Denpasar, Bali 80232, Indonesia \\ c Graduate School of Science and Engineering, Yamaguchi University, Ube Shi Tokiwadai 2-16-1, 7550092, Japan \\ ${ }^{d}$ Center for Remote Sensing and Ocean Sciences (CReSOS), Udayana University, PB Sudirman Street, Denpasar, \\ Bali 80232, Indonesia \\ * Correspondence: romaldox@gmail.com
}

Received: 21 September 2017; Accepted: 31 May 2018; Available online: 1 June 2018

\begin{abstract}
A single paragraph of about 250 words maximum. For research articles, abstracts should give a pertinent overview of the work. We strongly encourage authors to use the following style of structured abstracts, but without headings: 1) Background: Place the question addressed in a broad context and highlight the purpose of the study; 2) Methods: Describe briefly the main methods or treatments applied; 3) Results: Summarize the article's main findings; and 4) Conclusion: Indicate the main conclusions or interpretations. The abstract should be an objective representation of the article, it must not contain results which are not presented and substantiated in the main text and should not exaggerate the main conclusions.
\end{abstract}

Keywords: Soil fertility; NDVI; NDWI; N-total; Organic matter

\section{Introduction}

To increase the population of Lautém District as much as $57.543,59.787$ and 71.285 population based on census data $(2004,2010$ and 2013), indirectly cause land use change. The population increased followed the increasing human needs each year, the land use changes can lead to dryness of the land. Another factor that causes dryness is global climate change. Based on the amount of annual rainfall in Lautem District, in the northern part (Lautém/Moro) ranging from $500 \mathrm{~mm}$ to $1000 \mathrm{~mm}$ with a dry season ranges from 8 months. In the southern part (Lospalos, Tutuala, Mehara and Iliomar) of the amount of rainfall ranges between $1000 \mathrm{~mm}$ to $1500 \mathrm{~mm}$ with the dry season ranging from 5 months, medium temperature range between 23,60c-31.80c and maximum temperature is $380 \mathrm{c}$ from August to October.

Remote sensing is a science that provides information about an object or area on the surface of the Earth without direct study of the object being studied (Aggarwal, 2003). Remote sensing imagery can be used for specific studies, one of which mapping of soil fertility using data landsat-8 in Lautém District, Timor-Leste. According to previous study, combination of vegetation index and wetness index can be used for drought monitoring (Haikal, 2014). Wetness index is often used in soil science and hydrology to serve as an indicator of the region that has the potential for flooding. Wetness index can also be a parameter that is used to identify drought, forest fires, crop water requirements, and agricultural development. While the vegetation index is also very useful in science in agriculture, the vegetation index is used to determine the quality and distribution of vegetation (Nasipuri and Chatterjee 2009).Vegetation index will be estimated by using normalized difference vegetation index (NDVI) and wetness index will be estimated by Normalized Difference Water Index (NDWI). 
That the study of land index with satellite data in Lautem District, Timor-Leste is very necessary to produce in agriculture sector. Different soil characteristics (structure and texture) in Lautem District from crumb (mild) to weight and also has a land cover types ranging from open land to vegetated. With the remote sensing will be easier to identify them by using landsat- 8 OLI is the latest generation of Landsat data which started operation in early 2013.

\section{Method}

\subsection{Research Methods}

The method used in this research are 1) Observation in the field and 2) Observation through satellite image. Observations in the field, namely observation condition in the field with the soil sampling for analysis in the laboratory. The time observation and sampling of soil that is only in November 2013. The number of soil samples much as 25 points by random sampling. The observation satellite images are observations done with remote sensing techniques. Remote sensing data consists of the image recording data in accordance with the sampling time in the field namely from November 2013 to August 2015. The satellite images selected by the image that is free of clouds. To determine of the soil fertility in this research is to try to compare data from the field data with remote sensing data. The existing of the number of soil samples taken 15 samples to create models and 10 samples were used to create validation. Soil fertility data in general that is the data consisting of the physical, chemical and biological. But in this study are not all the data was used because only $\mathrm{N}$-total and organic matter.

\subsection{Study Area}

Lautem District is located at the end of the eastern part of the country East Timor with wide area of $1,813.11 \mathrm{~km}^{2}$. Geographically Lautem District located in $8^{0} 17^{\prime} 34.78^{\prime \prime} \mathrm{S}$ 8043'03.08"S and 126039'45.41"E - 127027'03.07"E (Figure 1).

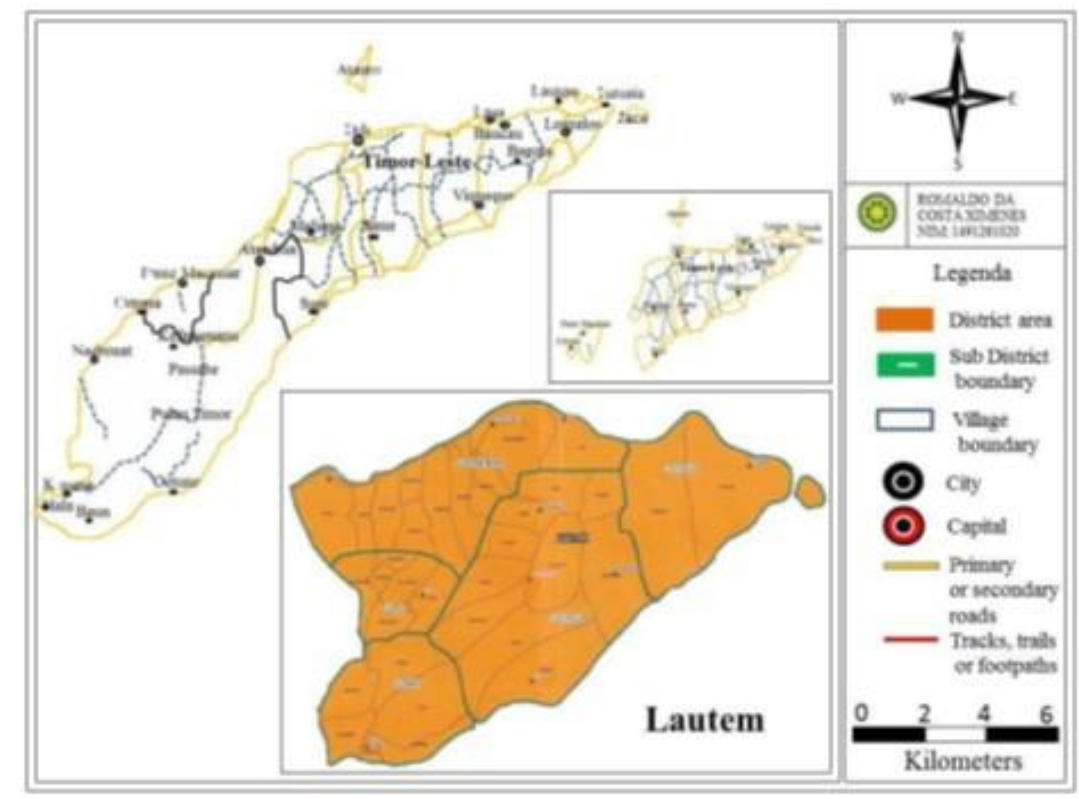

Figure 1. Research location

\subsection{Data Source}

\subsubsection{Primary Data Source}

First of all some references and materials were be collected. The theoretical base references and previous study are important to enhance the information. The materials of this research are Landsat-8 digital image in 2013, 2014 and 2015. 


\subsubsection{Secondary Data Source}

Secondary data used in this research is result analysis data from the N-total and organic matter. Data N-total and organic matter doing analysis in the laboratory of the soil by the Ministry of Agriculture and Fisheries (MAF) Timor-Leste since November 2013. The number of samples tested much as 25 samples have been completed with the coordinates of sampling.

\subsection{Framework of research}

Basic concepts in this study was to determine the fertility of the soil and the estimated soil index (NDVI and NDWI) using remote sensing techniques in Lautem District, TimorLeste to look for soil fertility parameters namely $\mathrm{N}$-total and organic matter. $\mathrm{N}$-total and organic matter here at first have data in situ in 2013 who later conducted the experiment the results of field data with remote sensing data in the same year.

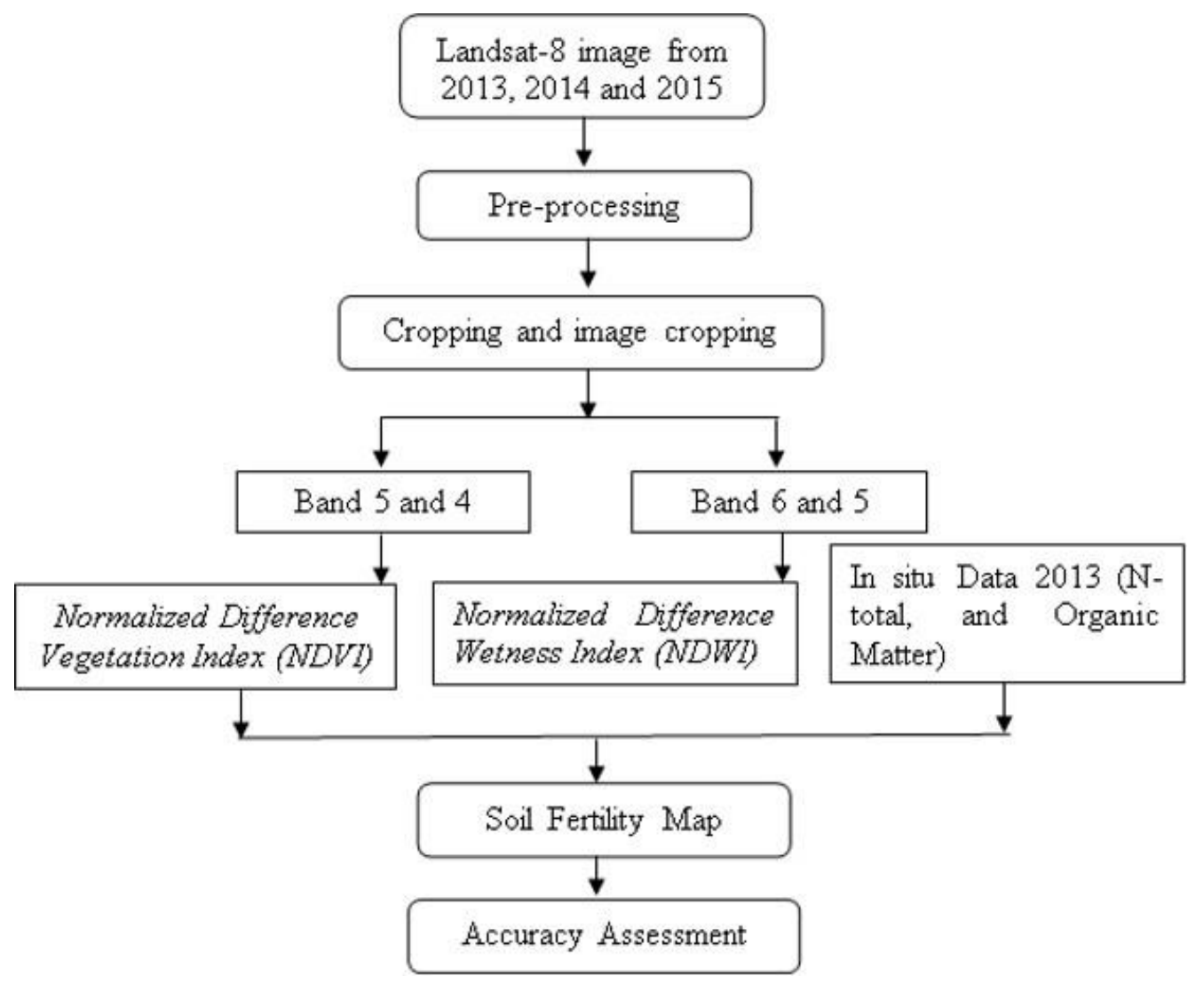

Figure 2. Framework of Research

\subsubsection{Download Image}

The initial phase of data processing is selection of satellite image data, because it can affect the data processing phase in the image later. Satellite image data can be selected and downloaded through the web site: http://www.usgs.gov/. The selected data were data the satellite Landsat-8 years 2013, 2014 and 2015.

\subsubsection{Image processing}

The first thing to do is to import the data and display it. Data processing most major image done before continued on next stage called pre-processing image, this step is carried out in order to get clear information from the image data. Stages of pre-processing image data consist of two main steps namely, conversion digital number to reflectance and reflectance correction by sun angle. 
- Conversion Digital Number to Reflectance

$$
p \lambda^{\prime}=M p x Q c a l+A p
$$

$\rho \lambda^{\prime}:$ Reflectance (\%)

$\mathrm{M} \rho$ : gain in specific (Reflectance_Mult band_X)

Qcal : Digital Number

A $\rho$ : Bias in specific (Reflectance_Add_X)

- Reflectance Correction by Sun Angle

$$
p \lambda=p \lambda ' \sin (\theta \mathrm{SE})
$$

$\rho \lambda \quad$ : Corrected Reflectance (\%)

$\theta \mathrm{SE}$ : Sun Elevation (degree)

\subsubsection{Image cropping}

Processing satellite image data which has a very large image size, so it is more focused on the study area that be studied namely Lautem District. These image cropping a part of the image used two coordinate namely the beginning of the coordinates for the image cropping result and coordinate the end which is point coordinates end from image result cropping.

\subsubsection{Analysis Normalized Difference Vegetation Index (NDVI)}

According to Assyakur and Adnyana (2009), NDVI were a method most often used to calculate and determine the value of the vegetation index. This is very good NDVI method used on areas that have the vegetation meeting. NDVI can show the level of yellowish green vegetation is also biomass vegetation with calculated using software ermapper and satellite image data landsat the measured from the band red (red) and near infrared band (NIR) on the spectrum of electromagnetic waves. With the existence of remote sensing, very easy calculate this index. Refer table 1 the NDVI value ranges between -1 until +1 which can be written in Equation below.

$$
N D V I=\frac{(N I R-\operatorname{Re} d)}{(N I R+\operatorname{Re} d)}=\frac{(\text { Band } 5-\text { Band } 4)}{(\text { Band } 5+\text { Band } 4)}
$$

Table 1. Classification NDVI (Wahyunto and Widagdo, 2003)

\begin{tabular}{ccc}
\hline Class & NDVI Value & Level of Greenness \\
\hline 1 & $-1<\mathrm{NDVI}<-0.03$ & Land not vegetated \\
2 & $-0.03<\mathrm{NDVI}<0.15$ & Greenish very low \\
3 & $0.15<\mathrm{NDVI}<0.25$ & Greenish low \\
4 & $0.25<\mathrm{NDVI}<0.35$ & Greenish medium \\
5 & $0.35<\mathrm{NDVI}<1$ & Greenish high \\
\hline
\end{tabular}

\subsubsection{Analysis Normalized Difference Wetness Index (NDWI)}

In analyzing the wetness index by landsat image, channel/band used is 5 and 4 . Band 5 including in the near infrared spectral energy (Near)/Near Infrared (NIR) with wavelength $0.85-0.88 \mu \mathrm{m}$, the purpose of band 5 are able to distinguish the type of vegetation that is detected and also the activity of the vegetation so that can restrict the body of water and also moisture in the land. While the band 4 including in the infrared is / middle infrared with wavelength $0.64-0.67 \mu \mathrm{m}$, band 4 useful to show the composition of moisture in the plant and moisture land, also can distinguish the snow and the clouds. 
Refer Table 2 the NDWI value ranges between -1 until +1 which can be written in Equation below.

$$
N D W I=\frac{(N I R-S W I R)}{(N I R+S W I R)}=\frac{(\text { Band } 5-\text { Band } 6)}{(\text { Band } 5+\text { Band } 6)}
$$

Table 2. Classification NDWI (Xu, 2006 refer to MNDWI)

\begin{tabular}{ccc}
\hline Class & Value NDWI & Level of Wetness \\
\hline 1 & $-1<\mathrm{NDWI}<0$ & Non-body water \\
2 & $0<\mathrm{NDWI}<0.33$ & Moderate wetness \\
3 & $0.33<\mathrm{NDWI}<1$ & High wetness \\
\hline
\end{tabular}

\subsubsection{Relationship NDVI with the in situ data.}

High NDVI value (positive) identifies the area vegetation grassland, scrub and forest Value index of vegetation can provide information on the percentage of vegetation cover, plant life index (Leaf Area Index), biomass plants, photosynthetic capacity, and estimate the absorption of carbon dioxide (CO2). Related with the data in situ (organic material and nitrogen), for example high NDVI values indicate that the organic material and nitrogen content is also high. If when the low NDVI values indicate that the organic material is low and automatically nitrogen content is also low.

\subsubsection{Relationship NDWI with in situ data}

NDWI value associated with soil wetness, when the value of wetness index in the surface is high with result NDWI, indicate that the results show that a higher level of wetness. In connection with the data in situ as a comparison that the results of the NDWI is high value means the level of wetness is also high, from the assumption that there can be categorized that if on the surface have the level of wetness higher assume that the fertility rate is high. If the value of reflectance NDWI is small with the same of the insitu data means shows that the level of the fertility of the soil is low.

\subsubsection{Analysis of Soil Fertility Index}

Analysis of the soil fertility index will be done after getting the results of the NDVI and NDWI. In this study will be developed algorithm to produce soil fertility map based on NDVI, NDWI and soil properties from the field. Soil fertility depends on the reflectance values on the surface of the earth, if color reflectance is dominated by the color green its means that soil fertility is fertile. Here are some of the assumptions relating to the fertility of the soil based on the combination of NDVI, NDWI and In situ data.

In this research determined of the soil fertility from satellite landsat- 8 is combination four parameters index namely NDVI, NDWI, index (N-total) and index (organic matter). From the four index was part in to determining of the soil fertility in Lautem District, Timor-Leste. Determined soil fertility used by formula

$$
\begin{gathered}
N D V I=\frac{(\text { Band } 5-\text { Band } 4)}{(\text { Band } 5+\text { Band } 4)} \\
N D W I=\frac{(\text { Band } 5-\text { Band } 6)}{(\text { Band } 5+\text { Band } 6)}
\end{gathered}
$$




$$
\operatorname{Index}(\mathrm{N}-\text { total })=\frac{x-\min (\text { Value })}{\max (\text { Value })-\min (\text { Value })}
$$

$\mathrm{x}=\mathrm{N}$-total

$$
\operatorname{Index}(\text { Organic matter })=\frac{x-\min (\text { value })}{\max (\text { value })-\min (\text { value })}
$$

$\mathrm{x}=$ Organic matter

$$
\text { Soil fertility index }=\frac{(5)+(6)+(7)+(8)}{4}
$$

\subsubsection{Accuracy Assessment}

Accuracy assessment in this research by the 2 methods namely: 1) Statistic analysis $0.05 \%$ and 2) T-Test Paired $1 \%$. This method used to determine accuracy data from data field analysis with data remote sensing analysis.

\section{Result and Discussion}

\subsection{Normalized Difference Vegetation Index (NDVI)}

Based on landsat-8 images analysis, NDVI in Lautém District, Timor-Leste in years of 2013, 2014 and 2015 was very from very low to very high (Table 3).

\begin{tabular}{|c|c|c|c|c|c|c|c|c|c|c|}
\hline \multirow{3}{*}{ NDVI Class } & \multirow{2}{*}{\multicolumn{2}{|c|}{$\begin{array}{l}2013 \\
2-N o v\end{array}$}} & \multicolumn{4}{|c|}{2014} & \multicolumn{4}{|c|}{2015} \\
\hline & & & \multicolumn{2}{|c|}{ 27-Apr } & \multicolumn{2}{|c|}{ 16-Jul } & \multicolumn{2}{|c|}{ 13-Mar } & \multicolumn{2}{|c|}{20 August } \\
\hline & Area $(\mathrm{Ha})$ & $\%$ & A.rea $(\mathrm{Ha})$ & $\%$ & Area $(\mathrm{Ha})$ & $\%$ & Area $(\mathrm{Ha})$ & $\%$ & Area (ha) & $\%$ \\
\hline Very low & 4450.50 & 2.21 & 417.06 & 0.21 & 1800.00 & 0.91 & 5543.64 & 2.70 & 152.55 & 0.07 \\
\hline Low & 30822.48 & 15.28 & 6327.72 & 3.12 & 13569.66 & 6.87 & 12832.83 & 6.25 & 18144.72 & 8.85 \\
\hline Moderate & 48165.39 & 23.88 & 19276.74 & 9.52 & 33415.02 & 16.92 & 27893.79 & 13.58 & 38588.76 & 18.82 \\
\hline High & 56216.70 & 27.88 & 43539.12 & 21.49 & 60651.45 & 30.71 & 47020.68 & 22.89 & 59188.86 & 28.87 \\
\hline Very high & 62007.12 & 30.75 & 133012.53 & 65.66 & 88090.74 & 44.60 & 112104 & 54.58 & 88916.04 & 43.38 \\
\hline Total Area & 201662.19 & 100 & 202573.17 & 100 & 197526.87 & 100 & 205394.94 & 100 & 204990.93 & 100 \\
\hline
\end{tabular}

Table 3. Classification NDVI by Satellite Landsat-8 in Lautém District, Timor-Leste 2013, 2014 , and 2015

Index NDVI from satellite landsat- 8 into five categories namely very low, low, moderate, high and very high. Very low class with the range -1 until -0,03 in 16 July 2014 is high $(24.32 \%)$ including clouds and low in 20 August $2015(0.07 \%)$. Low class with the range 0.04 until 0.15 in 02 November 2013 is high (15.28\%) and low in 27 April 2014 (3.12\%). Moderate class with the range 0.16 until 0.25 in 02 November 2013 is high $(23.88 \%)$ and low in 16 July 2014 (12.92\%). High class with the range 0.26 until 0.35 in 20 August 2015 is high (43.38\%) and low in 27 April $2014(21.49 \%)$. Very high class with the range 0.36 until 1 in 27 April 2014 is high (65.66\%) and low in 02 November $2013(30.75 \%)$. Very high vegetation level dominated in location area, 02 November 2013 is (30.75\%), 27 April 2014 is $(65.66 \%), 16$ July 2014 is (34.04\%), 13 Marc 2015 is $(54.58 \%)$ and 20 August 2015 is $(43.38 \%)$, Very high vegetation index mostly found in the southern part of the research area. Based on the condition that is located at the location of the research that indeed of the southern part of the vegetation level more meeting and still high compared with the condition of the vegetation that is located at the north. According with the season in Lautém District, Timor-Leste raining season start from November until July and dry season start from August until October. In the Northern part of the research 
location, annual rainfall ranges between 500-1000 mm compared the southern part of the research annual rainfall ranges between 1000-1500 $\mathrm{mm}$.

\subsection{Normalized Difference Wetness Index (NDWI)}

Based on landsat-8 images analysis, NDWI in Lautém District, Timor-Leste in years of 2013, 2014 and 2015 was low to high (Table 4).

Table 4. Classification NDWI by Satellite Landsat-8 in Lautém District, Timor-Leste 2013, 2014 , and 2015

\begin{tabular}{|c|c|c|c|c|c|c|c|c|c|c|}
\hline \multirow{3}{*}{ NDWI Class } & \multicolumn{2}{|c|}{2013} & \multicolumn{2}{|l|}{2014} & \multicolumn{2}{|c|}{2014} & \multicolumn{2}{|c|}{2015} & \multicolumn{2}{|c|}{2015} \\
\hline & \multicolumn{2}{|c|}{2 November } & \multicolumn{2}{|l|}{27 April } & \multicolumn{2}{|c|}{16 July } & \multicolumn{2}{|c|}{13 MArch } & \multicolumn{2}{|c|}{20 August } \\
\hline & Area $(\mathrm{Ha})$ & $\%$ & Area (Ha) & $\%$ & Area (Ha) & $\%$ & Area (Ha) & $\%$ & Area (Ha) & $\%$ \\
\hline Low & 768.42 & 0.38 & 3591.09 & 1.77 & 6811.92 & 3.32 & 887.76 & 0.43 & 32977.71 & 16.06 \\
\hline Modetrate & 18624.60 & 9.23 & 58585.23 & 28.92 & 104130.09 & 50.7 & 61884.45 & 30.13 & 111700.89 & 54.39 \\
\hline High & 182409.30 & 90.39 & 140396.85 & 69.31 & 94452.93 & 45.99 & 142622.73 & 69.44 & 60704.37 & 29.56 \\
\hline Total area & 201802.32 & 100 & 202573.17 & 100 & 205394.94 & 100 & 205394.94 & 100 & 205382.97 & 100 \\
\hline
\end{tabular}

Index NDWI from satellite landsat- 8 into three categories namely low, moderate and high. Low class with the range -1 until 0 in 20 August 2015 is high $(16.06 \%)$ and low in 02 November $2013(0.38 \%)$. Moderate class with the range 0.10 until 0.33 in 20 August 2015 is high (54.39\%) and low in 02 November 2013 (9.23\%), and High class with the range 0.33 until 1 in 02 November 2013 is high $(90.39 \%)$ and low in 20 August 2015 $(29.56 \%)$. High wetness level dominated in 02 November 2013 is $(90.39 \%)$, because Eastern churchmen there are over the function of land means and even the level of vegetation that is still in the natural conditions, in 27 April 2014 wetness index is still high $(69.31 \%)$, but in 16 July 2014 decrease to moderate class $(50.70 \%)$ This is most likely that the existence of forest destruction and over the function of the land. Like that 20 August 2015 wetness index more decrease to (54.39\%), different with 13 March 2015 is high $(69.44 \%)$ the level of high wetness possibility for a number of the high rainfall in this month.

The areas with the condition of the land that is damp and the vegetation of the meeting is the factor of high value of the index. If traced on a map and compared with the condition of the field that the level of the vegetation in the location of the research just variations. The value of negative wetness index shows the level of wetness low land and low vegetation, while high NDWI values of positive there is a high level of wetness. Agricultural land is dry which allows that the value of the index wetness is negative; the value of negative index shows the condition of the dry land. This index also shows that the lower the vegetation on the land is then wetness is extreme levels in the land are progressively lower, while if many vegetation and then meeting wetness index was high. In order to know the diversity of NDWI values in the study area, then you will need to know the factors that influence. In this research, these factors consist of the value of the density NDVI and types of land.

\subsection{Relationship Between N-Total and Remote Sensing Data}

Index N-total from satellite landsat-8 into five categories base on the Central of Soil Research (1983), category very low range -0.01 until 0.10 , category low range 0.10 until 0.20 , category moderate range 0.20 until 0.50 , category high range 0.50 until 0.75 and category very high range 0.75 until 1 .

The number of soil sample used in this study is 25 points. As much as 15 samples used to develop the model, and remaining 10 points utilized for validation. Based on the statistic analysis to find out the relationship between $\mathrm{N}$-Total and remote sensing data, NDVI the best relationship with $\mathrm{N}$-Total of the soil with the equation $\mathrm{y}=-0,657 \mathrm{x} 2+$ $1,272 \mathrm{x}-0,087$. Where $\mathrm{y}$ is N-total and $\mathrm{x}=$ NDVI (Figure 3). 

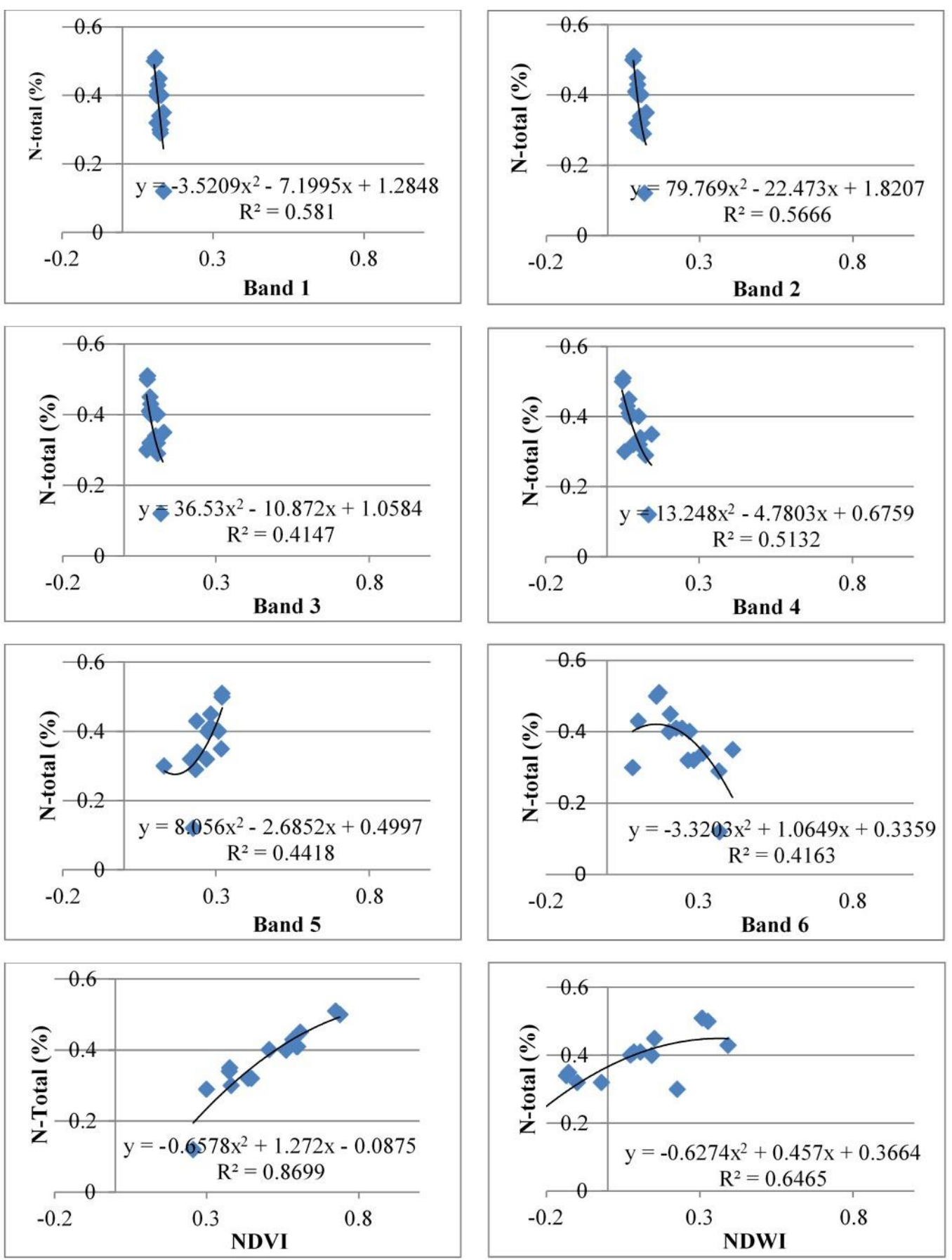

Figure 3. Relationship between $\mathrm{N}$-total from data field and remote sensing data in Lautém District, Timor-Leste.

Index N-total in location research are dominant moderate class and high class, category high class found in the southern part of the location area and low nitrogen found in the northern part. According with the annual rainfall in location research that rainfall in the southern part ranged between $1000 \mathrm{~mm}$ until $1500 \mathrm{~mm}$ different with in the northern part ranged between $500 \mathrm{~mm}$ until $1000 \mathrm{~mm}$. Related the Normalized Difference Vegetation Index (NDVI), shows that in southern part of location research indicated that vegetation is high compared with the northern part of the location research.

\subsection{Relationship Between Organic Matter and Remote Sensing Data}

Index organic matter from satellite landsat-8 into five categories base on Puslittanak, (2005). The category very low range 0.1 until 1.0, category low range 1.0 until 2.0, 
category moderate range 2.0 until 4.2 , category high range 4.2 until 6.0 and category very high range 6.0 until 8.0.

The number of soil sample used in this study is 25 points. As much as 15 samples used to develop the model, and remaining 10 points utilized for validation. Based on the statistic analysis to find out the relationship between organic matter and remote sensing data, NDWI the best relationship with Organic matter of the soil with the equation $y=$ $2.384 x 2+4.035 x+1.858$. Where $y$ is Organic matter and $x=$ NDWI (Figure 4 )
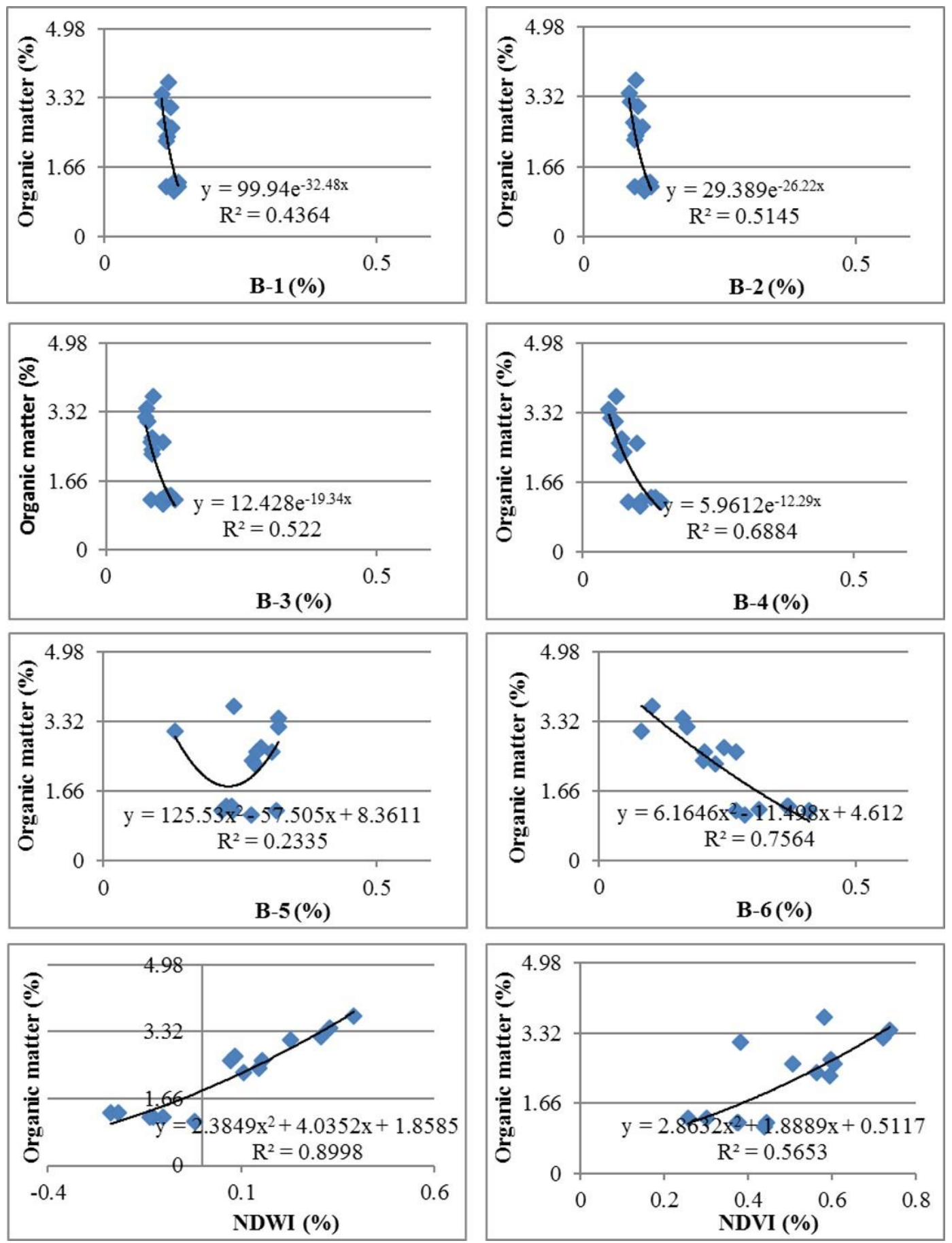

Figure 4. Relationship between organic matter from data field and remote sensing data in Lautém District, Timor-Leste.

Organic matter in location research dominant moderate class and high class, category high class found in the southern part of the location area and low organic matter found in the northern part. According with NDWI, high wetness index in the southern part is high compared in the northern part. Related that the colors of the soil type, maybe in southern 
part majority dark color of soil. Figure 5.6 shows classification organic matter map from satellite landsat-8 in Lautém District, Timor-Leste from 2013, 2014 and 2015. Blue color indicates water, red color indicates very high organic matter and green color indicated very low organic matter.

\subsection{Soil Fertility}

The value of the soil fertility divided into two categories, one is a high fertility level and zero is a low fertility level. The Table 5 shows soil fertility from by satellite landsat- 8 in Lautém District, Timor-Leste from 2013, 2014 and 2015.

Table 5. Soil fertility from Satellite Landsat- 8 in Lautém District, Timor-Leste from 2013, 2014, and 2015.

\begin{tabular}{cccccc}
\hline & \multicolumn{2}{c}{ Soil Fertility } \\
\hline & 2013 & \multicolumn{2}{c}{2014} & \multicolumn{2}{c}{2015} \\
\cline { 2 - 6 } 02 November & 27 April & 16 July & 13 March & 20 August \\
\hline Min. & 0.126 & 0.343 & 0.165 & 0.176 & 0.183 \\
Max. & 0.79 & 12.562 & 0.826 & 0.834 & 0.806 \\
Mean & 0.468 & 0.647 & 0.58 & 0.637 & 0.531 \\
\hline
\end{tabular}

The Table 5 shows that soil fertility in 02 November 2013 to 27 April 2014 is high, and tends to decrease soil fertility in 16 July 2014 to 20 August 2015. The range value from 0.468 to 0.647 is the beginning of the raining season that high. The amount of rainfall causing soil conditions become damp or wet so that the plant can produce N-total and organic ingredients be high. Different soil fertility in 16 July 2014 to 20 August 2015 show the soil fertility decrease from 0,58 to 0.531 is the beginning of the climate change. Causing low fertility in this case maybe the limited raining and increase temperature. Increases of the temperature can cause the soil to dry so that the produce of the N-total by plants to decrease. Decrease in biomass produced by plants can affect the amount of organic matter in the soil. If high organic matter in the soil indicated that the color of the soil is dark, nitrogen related with the vegetation. Indicator of the soil fertility in this case is vegetation index, wetness index, index $\mathrm{N}$-total and organic matter.

\subsection{Accuracy Assessment}

The results of the accuracy test of the $\mathrm{N}$-total and organic matter from data field with remote sensing data analysis by the statistic $0.05 \%$ (Figure 5 ) and T-Test paired $1 \%$ (Table 6) is not significant. The accuracy assessment from data field with remote sensing data not significant it means that the analysis result from the data field with result from the remote sensing analysis the value almost equal. Accuracy of the $\mathrm{N}$-total is $0.818(82 \%)$ while the accuracy of organic matter is $0.944(94 \%)$.
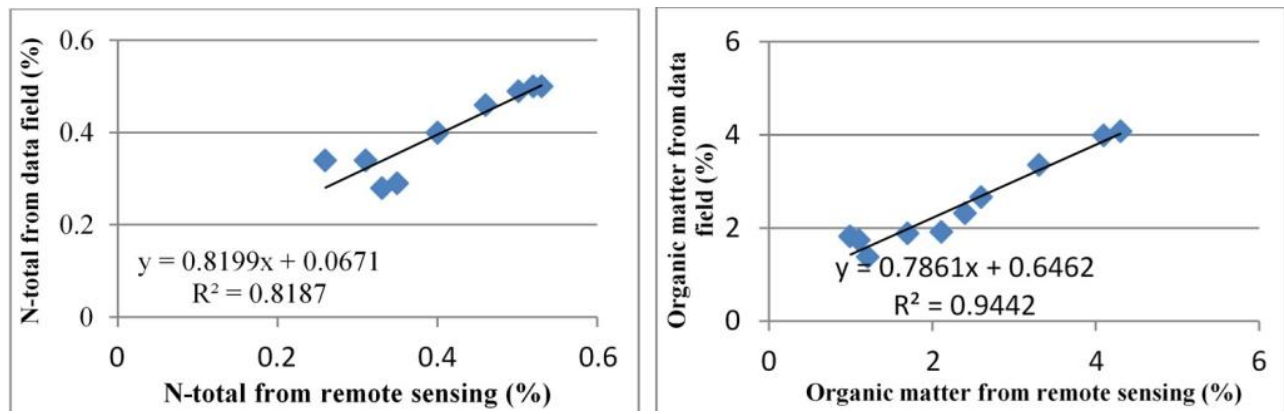

Figure 5. Accuracy N-total from data field with N-total from remote sensing (a) and accuracy organic matter from data field with organic matter from remote sensing data (b) in Lautém District, Timor-Leste. 
Table 6. Paired Samples Test

\begin{tabular}{|c|c|c|c|c|c|c|c|c|c|}
\hline & & \multicolumn{5}{|c|}{ Paired Differences } & \multirow[b]{5}{*}{$\mathrm{t}$} & \multirow[b]{5}{*}{ df } & \multirow{5}{*}{$\begin{array}{l}\text { Sig. }(2- \\
\text { tailed) }\end{array}$} \\
\hline & & \multirow[b]{4}{*}{ Mean } & \multicolumn{4}{|c|}{ 95\% Confidence } & & & \\
\hline & & & \multirow{3}{*}{$\begin{array}{c}\text { Std. } \\
\text { Deviation }\end{array}$} & \multirow{3}{*}{$\begin{array}{l}\text { Std. } \\
\text { Error } \\
\text { Mean }\end{array}$} & \multirow{2}{*}{\multicolumn{2}{|c|}{$\begin{array}{l}\text { Interval of the } \\
\text { Difference }\end{array}$}} & & & \\
\hline & & & & & & & & & \\
\hline & & & & & Lower & Upper & & & \\
\hline Pair 1 & $\begin{array}{l}\text { N-Total from data field - N-Total } \\
\text { from data remote sensing }\end{array}$ & 0.00 & .03 & .01 & -.02 & .02 & -.01 & 9 & 0.99 \\
\hline \multirow[t]{2}{*}{ Pair 1} & Organic Matter from data field - & & & & & & & & \\
\hline & $\begin{array}{l}\text { Organic Matter from data remote } \\
\text { sensing }\end{array}$ & -.14 & 0.34 & 0.11 & -.38 & 0.11 & -1.26 & 9.00 & 0.24 \\
\hline
\end{tabular}

\section{Conclusion and Suggestion}

\subsection{Conclusion}

1. The estimation of NDVI and NDWI by landsat-8 in Lautem District, Timor-Leste showed that the southern parts of Lautem District are higher compared with the northern parts because of the soil structure and the texture in the southern part is more crumbs (mild).

2. The estimation of soil fertility from the NDVI and NDWI by landsat-8 in Lautem District showed that soil high fertility in 02 November 2013 and 27 April 2014 and tends to decrease soil fertility in 16 July 2014 to 20 August 2015.

3. The accuracy assessment between the field observation data and remote sensing data showed approximately equal. Accuracy for $\mathrm{N}$-total was $82 \%(\mathrm{R} 2=0.82)$ and for organic matter was $94 \%(\mathrm{R} 2=0.94)$.

\subsection{Suggestion}

1. Need to existence research further in several locations with more data so able to know the accuracy level from remote sensing data.

2. Need existence data related with the soil fertility for example rainfall, $\mathrm{pH}$ and soil moisture using remote sensing data to calculate soil fertility.

\section{References}

Aggarwal, S. (2003). Principles of Remote Sensing. In Proceeding of a Training Workshop. Dehra Dun, India, 7-11 July 2003 (pp.23-38).

As-syakur, A. R., \& Adnyana, I. W. S. (2009). Analisis indeks vegetasi menggunakan citra ALOS/AVNIR-2 dan sistem informasi geografi (SIG) untuk evaluasi tata ruang kota Denpasar. Bumi Lestari, 9(1), 1-11.

Haikal, T. (2014). Analisis Normalized Difference Wetness Index (NDWI) dengan Menggunakan Data Citra Landsat 5 TM (Studi Kasus: Provinsi Jambi Path/Row: 125/61). Skripsi. Bogor, Indonesia: Departemen Geofisika dan Meteoroli, Fakultas Matematika dan Ilmu Pengetahuan Alam, Institut Pertanian Bogor.

Wahyunto, Ritung, S., \& Widagdo. (2003). The final report of Remote Sensing Technology for the Efficiency of Inventory and Monitoring of Land Resource. The porch Research Land. Center for Research and Development of the Land and Agroklimat. The Agency for Agricultural Research and Development.

$\mathrm{Xu}, \mathrm{H}$. (2006). Modification of normalised difference water index (NDWI) to enhance open water features in remotely sensed imagery. International journal of remote sensing, 27(14), 3025-3033.

(C) 2018 by the authors; licensee Udayana University, Indonesia. This article is an open access article distributed under the terms and conditions of the Creative Commons Attribution (CC-BY) license (http://creativecommons.org/licenses/by/4.0/). 